\title{
Pengaruh Alat Peraga Mobil Garis Bilangan terhadap Hasil Belajar Matematika Peserta Didik Kelas VI SD Negeri 6 Klablim
}

\author{
$\operatorname{Alman}^{1}$, Julisa Palaribato Pulung ${ }^{2} \&$ Heny Sri Astutik ${ }^{3}$ \\ Program Studi PGSD, Universitas Pendidikan Muhammadiyah Sorong, Indonesia \\ Program Studi Pend. Matematika, Universitas Pendidikan Muhammadiyah Sorong, Indonesia \\ ${ }^{凶}$ E-mail: Almankuntara87@gmail.com
}

\begin{abstract}
Abstrak
Penelitian ini bertujuan untuk mengetahui pengaruh penggunaan alat peraga mobil garis bilangan terhadap hasil belajar operasi hitung bilangan bulat peserta didik. Metode yang digunakan dalam penelitian ini adalah metode pra eksperimen dengan desain penelitian One Shot Case Study Design. Data menunjukkan rata-rata skor observasi guru (peneliti) dan peserta didik sebesar $100 \%$ dengan kriteria sangat baik. Hasil analisis ketuntasan belajar pada nilai rata - rata posttest 69,13 . Uji normalitas hasil belajar postest peserta didik memiliki taraf signifikansi 0,200 >0,05. Uji hipotesis diperoleh $\mathrm{t}_{\text {hitung }}$ sebesar 3,712 dengan $\mathrm{dk}=\mathrm{n}-1(23-1=22)$ diperoleh $\mathrm{t}_{\text {tabel }}$ sebesar 1.717. Berdasarkan hasil analisi data nilai yaitu $t_{\text {hitung }}>t_{\text {tabel }}(3.712>1.717)$, dengan besarnya taraf signifikansi 0,05 , yakni $(0,001<0,05)$ maka Hipotesis diterima, Dengan demikian dapat disimpulkan bahwa terdapat pengaruh alat peraga mobil garis bilangan terhadap hasil belajar matematika materi operasi hitung bilangan bulat pada peserta didik kelas VI SD Negeri 6 Klablim Kota Sorong.
\end{abstract}

Kata Kunci: Alat Peraga Mobil Garis Bilangan; Hasil Belajar.

\begin{abstract}
This study aims to determine the effect of the use of the car line props to the learning outcomes of students' integer operations. The method used in this study is the pre-experimental method with the One Shot Case Study Design research design. The data shows the average observation score of teachers (researchers) and students by 100\% with very good criteria. The results of the analysis of mastery learning at posttest mean value of 69.13. Test the normality of students' posttest learning outcomes has a significance level of 0.200>0.05. Hypothesis testing obtained $t_{\text {value }}$ of 3,712 with $d k=$ $n-1(23-1=22)$ obtained ttable of 1,717. Based on the results of the analysis of the value of data that is $t_{\text {value }}>t_{\text {table }}(3,712>1,717)$, with a significance level of 0.05 , namely $(0.001<0.05)$, the hypothesis is accepted, thus it can be concluded that there is the influence of the car number line props on learning outcomes Mathematics of arithmetic operations of integers in grade VI students of SD Negeri 6 Klablim Sorong City.
\end{abstract}

Keywords: Line Car Model Prop; Learning Outcomes. 


\section{PENDAHULUAN}

Matematika merupakan salah satu mata pelajaran yang wajib dipelajari oleh peserta didik di sekolah dimulai sejak anak memasuki pendidikan sekolah dasar, karena dalam kehidupan sehari-hari sering dijumpai pengaplikasian pembelajaran matematika pada materi seperti menghitung uang. Mempelajari matematika berawal dari mempelajari bilangan, yang salah satu dari klasifikasi bilangan tersebut adalah bilangan bulat. Operasi hitung bilangan bulat biasanya telah dikenal oleh anak semenjak masih usia dini, terutama pada operasi hitung penjumlahan dan pengurangan bilangan bulat walaupun anakanak itu sendiri belum menyadari bahwa ia sedang melakukan operasi hitung. Hal itu merupakan potensi dasar anak yang sangat perlu dikembangkan oleh orang tua dan gurunya. Sekolah dasar mulai dikembangkan oleh guru dengan cara menanamkan dasar-dasar pengetahuan pada peserta didik melalui berbagai bidang pengajaran, terutama melalui pembelajaran matematika.

Wawancara dengan wali kelas VI SD N 6 Kablim Kota Sorong bahwa hasil nilai rapor matematika semester genap memuaskan akan tetapi pada nilai ulangan harian materi operasi hitung bilangan bulat masih banyak peserta didik yang menjawab salah. Serta berdasarkan hasil tes yang peneliti lakukan pada tanggal 18 Mei 2019 $65 \%$ peserta didik salah menjawab soal mengenai operasi bilangan bulat khususnya pada bilangan bulat negatif. Peserta didik hanya memahami operasi hitung bilangan bulat pada angka positif saja. Padahal peserta didik kelas VI telah mempelajari materi tersebut di semester I.

Kurangnnya pemahaman peserta didik dalam operasi hitung bilangan bulat dimungkinkan oleh beberapa faktor yang mempengaruhinya dalam kegiatan belajar mengajar. Biasanya guru dalam menjelaskan konsep operasi hitung bilangan bulat tidak melibatkan peserta didik secara langsung, sehingga sulit untuk memahaminya. Hal tersebut mengakibatkan pembelajaran kurang bermakna, sedangkan operasi hitung bilangan bulat harus sudah dikuasai oleh peserta didik untuk pembelajaran yang lebih tinggi. Peserta didik yang tidak menguasai operasi hitung bilangan bulat akan mengalami kesulitan dalam mengikuti pelajaran selanjutnya yang dapat berakibat peserta didik tidak menyukai matematika.

Media dibutuhkan untuk dapat membantu memperjelas apa yang akan disampaikan guru dan mudah dipahami dan dimengerti oleh peserta didik. Media memungkinkan terjadinya interaksi langsung antara peserta didik dengan peserta didik, peserta didik dengan guru dan juga peserta didik dengan lingkungannya. Guru tidak cukup memiliki pengetahuan tentang media saja, namun guru juga harus memiliki kemampuan untuk memilih dan menggunakan media dengan baik. Salah satu bentuk media yaitu alat peraga. Alat peraga sangat diperlukan untuk membantu peserta didik SD dalam memahami konsep yang dipelajari dan meningkatkan minat peserta didik dalam proses pembelajaran matematika. Berdasarkan hasil penelitiaan yang dilakukan oleh Firdaus (2011: 63) bahwa pemahaman konsep matematika peserta didik yang diberikan alat peraga lebih baik dibandingkan peserta didik yang tidak diberikan alat peraga dalam proses pembelajaran.

Berkaitan dengan hal tersebut di atas, maka dalam pembelajaran matematika materi operasi hitung bilangan bulat memerlukan alat peraga, diantaranya guru dapat menggunakan alat peraga mobil garis biangan. Alat peraga mobil garis bilangan merupakan salah satu solusi dalam menghitung operasi hitung bilangan bulat. Alat peraga mobil garis 
bilangan yang bisa dibuat sendiri oleh guru, bahan-bahannya sangat sederhana, mudah didapat, dan harga terjangkau. Melalui penggunaan alat peraga mobil garis bilangan menjadikan peserta didik akan mampu memecahkan masalah sehingga konsep operasi hitung bilangan bulat mudah diselesaikan oleh peserta didik, di samping itu peserta didik akan lebih aktif dalam pembelajaran bukan hanya sekedar mendengarkan penjelasan dari guru. Sifat alat peraga ini membantu memperjelas konsep-konsep operasi hitung bilangan bulat yang abstrak menjadi konkret.

Hasil belajar adalah suatu penilaian akhir dari proses dan pengenalan yang telah dilakukan berulang-ulang, serta akan tersimpan dalam jangka waktu lama atau bahkan tidak akan hilang selama-lamanya karena hasil belajar turut serta dalam membentuk pribadi individu yang selalu ingin mencapai hasil yang lebih baik lagi sehingga akan merubah cara berpikir serta menghasilkan prilaku yang lebih baik (Yunani, 2015: 13). Domain hasil belajar adalah perilaku-perilaku kejiwaan yang akan dirubah dalam proses pendidikan Purwanto (Juwariyah, 2015: 24). Perilaku kejiwaan itu dibagi dalam tiga domain: kognitif, afektif, dan psikomotorik. Hasil belajar kognitif adalah perubahan tingkah laku yang terjadi dalam kawasan kognisi yaitu kemampuan menghafal, pemahaman, penerapan, analisis, sintesisdan evaluasi. Hasil belajar afektif meliputi level: penerimaan, partisipasi, penilaian, organisasi dan karakterisasi. Hasil belajar psikomotorik meliputi level: persepsi, kesiapan, gerakan terbimbing, gerakan terbiasa, gerakan komplek dan kreatifitas. Domain hasil belajar dalam penelitian ini, dibatasi oleh peneliti dalam aspek kognitif. faktor sekolah yang mempengaruhi hasil belajar mencakup : metode mengajar, model pembelajaran, kurikulum, perlengkapan di sekolah/ alat pelajaran, keadaan ruangan, jumlah murid per kelas dan pelaksanaan tata tertib sekolah Dalyono (Yuliastuti, 2014: 2830).

Alat peraga adalah benda konkret yang dibuat dengan sengaja untuk menerangkan atau mewujudkan konsep matematika dan dapat merangsang pikiran dan perhatian peserta didik sehingga dapat mendorong proses belajar peserta didik. Dengan alat peraga, konsep matematika yang semulanya abstrak dapat dilihat melalui benda konkret oleh peserta didik, sehingga peserta didik dapat melihat dan terlibat secara langsung, tidak hanya mengangan-angan atau membayangkannya saja (Septiyana, 2017: 17).

Penggunaan alat peraga dalam proses pembelajaran memiliki tujuan-tujuan yang hendak dicapai agar proses pembelajaran sehingga proses pembelejaran menjadi berkualitas. Alat peraga berfungsi untuk menerangkan atau memperagakan suatu mata pelajaran dalam proses belajar mengajar. Dalam kegiatan belajar mengajar guru harus mampu menjelaskan konsep kepada siswanya (Suwardi, Masni, E.F., Rohayati, 2014). Alat peraga mampu menyajikan fenomena fenomena yang bersifat abstrak ke dalam bentuk konkrit yang bisa dilihat, dipegang, atau diubah-ubah sehingga materi abstrak mudah dipahami. Alat peraga merupakan salah satu media yang dapat digunakan untuk melatihkan keterampilan proses sains dan sikap ilmiah siswa (Meyrika Maharani, Mustika Wati, Sri Hartini, 2017). Penggunaan alat peraga dapat membantu mewujudkan situasi belajarpembelajaran yang efektif, mempercepat proses belajar-pembelajaran dan membantu siswa dalam menangkap pengertian yang diberikan guru, serta dapat mempertinggi mutu belajar-pembelajaran Nana Sudjana (St. Hasmiah Mustamin, 2018). Adapun beberapa tujuan penggunaan alat peraga menurut 
Purwanto (2014: 24-25) sebagai berikut: memberikan kemampuan berpikir matematika secara kreatif, mengembangkan sikap yang menguntungkan ke arah berpikir matematika, menunjang matematika di luar kelas, yang menunjukkan penerapan matematika dalam keadaan sebenarnya dan memberikan motivasi dan memudahkan abstraksi.

Alat peraga mobil garis bilangan yang dimaksud di sini adalah alat peraga yang dibuat penulis sendiri dalam proses belajar di kelas IV dalam materi "operasi hitung bilangan bulat". Alat peraga mobil garis bilangan yang berbentuk persegi panjang yang terdapat bilangan positif, nol dan negatif. Pada bagian atas permukaan terdapat mobil mainan yang bisa berjalan maju dan mundur. Pembuatan alat peraga mobil garis bilangan diperlukan bahanbahan seperti tripleks, kayu, kertas origami, kertas cover dan lem.

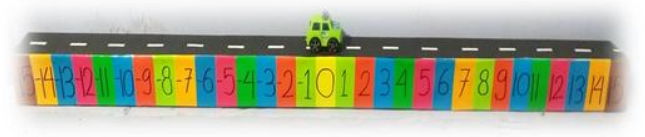

Gambar 1. Alat Peraga Mobil Garis

Peserta didik diberi panduan bahwa posisi awal mobil berada di angka 0 dan menghadap ke arah kanan. Operasi penjumlahan berarti mobil bergerak maju, dan operasi pengurangan berarti mobil bergerak mundur, jika melibatkan bilangan negatif (-) berarti mobil berbalik arah. Fajar Triyanto dan Joko Rofian (2018), media pembelajaran mogabil (mobil garis bilangan) efektif terhadap hasil belajar matematika materi operasi hitung bilangan bulat peserta didik kelas.

Dari uraian yang telah dijabarkan di atas, maka perlu suatu penelitian tentang Pengaruh Alat Peraga Mobil Garis Bilangan Terhadap Hasil Belajar Matematika Materi Operasi Hitung Bilangan Bulat pada Peserta didik Kelas VI SD Negeri 6 Klablim Kota
Sorong. Tujuan penelitian ini adalah untuk mengetahui apakah terdapat pengaruh alat peraga mobil garis bilangan terhadap hasil belajar matematika materi operasi hitung bilangan bulat pada peserta didik kelas VI SD Negeri 6 Klablim Kota Sorong.

\section{METODE PENELITIAN}

Jenis penelitian yang digunakan peneliti yaitu penelitian pra-eksperimen dengan desain One-Shot Case Study. Dalam penelitian ini peneliti memberikan perlakuan alat peraga mobil garis bilangan lalu memberikan posttest. Posttest ini digunakan untuk melihat pengaruh alat peraga mobil garis bilangan terhadap hasil belajar mateatika materi operasi hitung bilangan bulat. Posttes terdiri dari 20 soal pilihan ganda (PG) materi operasi hitung bilangan bulat, (b) Observasi.

Observasi atau pengamatan dalam penelitian ini dilakukan pada saat proses pembelajaran berlangsung dan juga keterlaksanaan pembelajaran dengan penggunaan alat peraga mobil garis bilangan. Observasi dilakukan oleh guru kelas dengan cara pengamatan mengenai pelaksanaan pembelajaran di dalam kelas yang melibatkan aktivitas guru dalam mengajar dengan menggunakan alat peraga mobil garis bilangan dalam proses pembelajaran serta observasi aktivitas belajar peserta didik selama proses pembelajaran berlangsung, (c) Dokumentasi. Dokumentasi yang dibutuhkan berupa keterangan dan hal-hal yang membuktikan adanya suatu kegiatan yang didokumentasikan.

Data didokumentasikan dengan menggunakan kamera Handphone. Pendokumentasian dilakukan tidak hanya proses pembelajaran saja, melainkan juga sikap peserta didik dalam mengikuti pembelajaran dan guru yang sedang melakukan pembelajaran.

Sebelum melakukan analisis data dengan analisis deskriptif kuantitatif ada beberapa uji 
prasyarat yang harus dilakukan terlebih dahulu, yaitu: (a) Uji Normalitas bertujuan untuk mengetahui apakah data yang terjaring dari masing-masing variabel berdistribusi normal atau tidak. Uji normalitas ini menggunakan metode Kolmogorov-Smirnov (Uji K-S.), (b) Uji Hipotesis yang digunakan Uji one sample $\mathrm{t}$ test merupakan uji yang untuk satu sample data. Hasil dari satu sample tersebut dibandingkan dengan suatu value atau nilai konstanta tertentu. Sehingga dari perbandingan tersebut dapat diketahui apakah sample data yang kita punya lebih tinggi atau lebih rendah dari value yang telah ditetapkan. Syaratnya dalam uji ini adalah data yang digunakan merupakan data kuantitatif dan berdistribusi normal.

\section{HASIL DAN PEMBAHASAN}

Hasil observasi aktifitas guru (peneliti) dan peserta didik dalam pembelajaran dengan menggunakan alat peraga mobil garis bilangan yang di observasi oleh guru kelas sebagai berikut

Tabel 1. Rekpitulasi Hasil Observasi Aktivitas Guru dan Siswa

\begin{tabular}{llcl}
\hline No & Langkah- langkah & Guru & Siswa \\
\cline { 3 - 4 } & & Ya Tidak & Ya Tidak \\
\hline 1 & Kegiatan Pendahuluan & $\checkmark$ & $\checkmark$ \\
2 & Kegiatan Inti & $\checkmark$ & $\checkmark$ \\
3 & Kegiatan Akhir & $\checkmark$ & $\checkmark$ \\
\hline
\end{tabular}

Dari tabel 1 menunjukkan bahwa guru dan siswa dapat melaksanakan pembelajaran dengan SANGAT BAIK mengingat setiap poin pengajaran $(100 \%)$ penilaian telah terpenuhi.

Data hasil postest menunjukkan bahwa banyaknya kelas ada 6 dengan panjang tiap interval kelas adalah 10. Nilai yang paling banyak diperoleh peserta didik terletak pada interval 75 - 84 yaitu sebesar 26\% (6 peserta didik dari 23 peserta didik). Sedangkan nilai yang paling sedikit diperoleh terletak pada interval $35-44$ yaitu sebesar 4\% (1 peserta didik dari 23 peserta didik). Nilai rata-rata diperoleh untuk nilai postest ini adalah 69.13. lebih lengkap dapat dilihat pada tabel 2, berikut;

Tabel 2. Tabel Distribusi Frekuensi Soal

\begin{tabular}{cccc}
\multicolumn{4}{c}{ Postest } \\
\hline \multirow{3}{*}{ Nilai } & \multicolumn{3}{c}{ Frekuensi } \\
\cline { 2 - 4 } & Absolut & Kumulatif & Relatif \% \\
\hline $35-44$ & 1 & 1 & 4 \\
$45-54$ & 2 & 3 & 9 \\
$55-64$ & 4 & 7 & 17 \\
$65-74$ & 5 & 12 & 22 \\
$75-84$ & 6 & 18 & 26 \\
$85-94$ & 5 & 23 & 22 \\
\hline
\end{tabular}

Uji normalitas digunakan untuk menguji data apakah berdistribusi normal atau tidak. Untuk menguji normalitas peneliti menggunakan rumus kolmogorov-smirnov. Pengujian normalitas dilakukan terhadap hasil belajar peserta didik dan diperoleh dari perhitungan dengan menggunakan software statistik diketahui hasil belajar posttest peserta didik kelas VI memiliki taraf signifikansi $0,200>0,05$ sehingga dapat disimpulkan bahwa kelas VI sebagai kelas berdistribusi normal. Hal ini menunjukkan bahwa data dalam penelitian memiliki varian yang sama, dan data layak digunakan untuk uji selanjutnya, yaitu uji hipotesis. Lebih jelas dapat dilihat pada tabel 3 .

Tabel 3. Uji Normalitas Kolmogorov Smirnov

\begin{tabular}{rccc}
\hline Jenis Tes & Asymp. Sig & A & Keterangan \\
\hline Posttest & 0,200 & 0,05 & $0.200>0,05$
\end{tabular}

Setelah uji prasyarat (uji normalitas) terpenuhi, maka selanjutnya adalah uji hipotesis. Dalam penelitian ini untuk pengujian hipotesis peneliti menggunakan uji $t$ atau biasa disebut $t-$ test. Uji hipotesis dilakukan dengan cara yaitu menggunakan software statistik.

Pada pengujian hipotesis digunakan uji $-\mathrm{t}$ test one sample test karena hanya terdapat satu varian dimana data yang diuji yaitu hasil posttest berdasarkan hasil perhitungan maka diperoleh thitung sebesar 3.712 dengan $\mathrm{dk}=\mathrm{n}$ 
- 1 (23-1=22) diperoleh ttabel sebesar 1.717. Berdasarkan hasil analisis data yaitu nilai thitung > ttabel $(3.712>1.717)$, dengan besarnya taraf signifikansi 0,05 , yakni $(0,001<0,05)$ maka Hipotesis diterima, berarti dapat dinyatakan bahwa terdapat pengaruh alat peraga mobil garis bilangan terhadap hasil belajar matematika materi operasi hitung bilangan bulat pada peserta didik kelas VI SD Negeri 6 Klablim Kota Sorong. Lebih jelasnya dapat dilihat pada tabel 4.

Tabel 4. Uji One Sample T-test

\begin{tabular}{cccc}
\hline & T & Df & Sig. (2 tailed) \\
\hline Postest & 3.712 & 22 & .001
\end{tabular}

Hasil penelitian ini bisa di katakan sama atau berhasil dilakukan oleh peneliti dengan di dukung oleh penelitian terdahulu yaitu penelitian yang dilakukan oleh Fajar Triyanto, Joko Peserta didiknto dan Rofian tahun 2018 yang berjudul Keefektifan Media Pembelajaran Mogabil Terhadap Hasil Belajar Matematika Peserta didik Kelas IV SDN 02 Baleraksa Purbalingga yang menyimpulkan bahwa alat peraga mogabil (mobil garis bila- ngan) efektif terhadap hasil belajar matematika materi operasi hitung bilangan bulat peserta didik. Hal ini dapat dilihat pada analisis uji hipotesis untuk menguji efektif atau tidaknya alat peraga Mobil Garis Bilangan terhadap hasil belajar diperoleh bahwa hasil post-test lebih tinggi dibanding hasil pretest kemudian dilakukan uji $\mathrm{t}$ diperoleh thitung > ttabel yaitu 15,36>2,048 maka H0 ditolak dan Ha diterima.

Dari hasil pengujian data di atas, peneliti dapat menyimpulkan bahwa dari penelitian yang dilakukan di peroleh hasil bahwa terdapat pengaruh alat peraga mobil garis bilangan terhadap hasil belajar matematika materi operasi hitung bilangan bulat pada peserta didik kelas VI SD Negeri
6 Klablim Kota Sorong.

\section{KESIMPULAN}

Berdasarkan hasil penelitian yang didasarkan pada analisis data dan pengujian hipotesis, maka kesimpulan yang dapat dikemukakan dalam penelitian ini yaitu terdapat pengaruh alat peraga mobil garis bilangan terhadap hasil belajar matematika peserta didik kelas VI SD Negeri 6 Klablim Kota Sorong tahun ajaran 2019/2020. Hal ini ditunjukkan oleh nilai thitung $=3.712$, sedangkan ttabel pada taraf signifikasi 5\% adalah 1.717 ,. Karena thitung > ttabel maka Hipotesis diterima.

\section{DAFTAR RUJUKAN}

Hendrayana, S. (2017). Meningkatkan Keterampilan Berpikir Rasional Siswa Melalui Model Sains Teknologi Masyarakat pada Konsep Sumber Daya Alam. Pendas: Jurnal Ilmiah Pendidikan Dasar, 2(1), 73-98

Firdaus, Ahmad L. (2011). Penggunaan Alat Peraga Mobil Garis Bilangan terhadap Pemahaman Konsep Matematika Siswa pada Materi Bilangan. Skripsi Sarjana, Fakultas Tarbiyah Dan Keguruan UIN Syarif Hidayatullah, Jakarta.

Juwariyah, Siti. (2015). Peningkatan Hasil Belajar Siswa Melalui Pembelajaran Kooperatif Tipe STAD (Student Team Achievement Division) pada Pokok Bahasan Perjuangan Dakwah Nabi Muhammad Saw. Skripsi. Fakultas Tarbiyah Universitas Islam Negeri Walisongo, Semarang.

Meyrika Maharani, Mustika Wati, Sri Hartini. (2017). Pengembangan Alat Peraga Pada Materi Usaha Dan Energi Untuk Melatihkan Keterampilan Proses Sains Melalui Model Iquiry Discovery Learning (IDL) Terbimbing. Berkala Ilmiah Pendidikan Fisika. Vol 5 no.3, Oktober 2017. Hal. 351-367.

Purwanto, Herey. (2014). Pengaruh Penggunaan Alat Peraga Terhadap Hasil Belajar Operasi Hitung Penjumlahan dan Pengurangan Bilangan Bulat Siswa Kelas 
IV Sekolah Dasar Islam Daru Mu'minin Larangan. Skripsi Sarjana, Fakultas Ilmu Tarbiyah dan Keguruan Universitas Islam Negeri Syarif Hidayatullah, Jakarta, 2014.

Septiyana, Dwi. (2017). Penggunaan Alat Peraga Dakota untuk Meningkatkan Prestasi Belajar FPB dan KPK pada Siswa Kelas IV SDN Kalitengkek. Skripsi Sarjana, Fakultas Keguruan dan Ilmu Pendidikan Universitas Muhammadiyah Purworejo, Purworejo.

St. Hasmiah Mustamin (2018). Penggunaan Alat Peraga Dalam Mengatasi Kesulitan Belajar Matematika Materi Pecahan Pada Siswa Kelas V. Jurnal Pendidikan Dasar Islam, Vol. 5 No. 2, Desember 2018, pp. 170-18.

Hendrayana, S. (2017). Meningkatkan Keterampilan Berpikir Rasional Siswa Melalui Model Sains Teknologi Masyarakat pada Konsep Sumber Daya Alam. Pendas: Jurnal Ilmiah Pendidikan Dasar, 2(1), 73-98
Suwardi, Masni, E.F., Rohayati. (2014) Pengaruh Penggunaan Alat Peraga terhadap Hasil Pembelajaran Matematika pada Anak Usia Dini Suwardi, Masni Erika Firmiana, Rohayati. Jurnal Al-Azhar Indonesia Seri Humaniora, Vo. 2, No.4, September 2014. hal 297-305.

Yuliastuti, H. (2014). Meningkatkan Hasil Belajar Matematika pada Materi Penjumlahan dan Pengurangan Bilangan Bulat dengan Model Pembelajaran Kooperatif tipe STAD. Skripsi Sarjana, Fakultas Ilmu Pendidikan Universitas Negeri Yogyakarta, Yogyakarta.

Yunani. (2015). Upaya Meningkatan Hasil Belajar Siswa pada Mata Pelajaran PAI dalam Mengenal Malaikat dan Tugasnya Melalui Metode Make a Match di Kelas IV SD Negeri 103 Palembang. Skripsi Sarjana, Fakultas Tarbiyah dan Keguruan Universitas Islam Negeri (UIN) Raden Patah, Palembang. 